\title{
LEISURE-TIME PHYSICAL INACTIVITY AMONG HEALTHCARE WORKERS
}

\section{SAULO VASCONCELOS ROCHA ${ }^{1}$, ALINE RODRIGUES BARBOSA ${ }^{2}$, and TANIA MARIA ARAÚJO ${ }^{3}$}

${ }^{1}$ State University of the Southwest of Bahia, Jequié, Brazil

Health Department II

${ }^{2}$ Federal University of Santa Catarina, Florianopólis, Brazil

Sports Center

${ }^{3}$ State University of Feira de Santana, Feira de Santana, Brazil

Health Department

\begin{abstract}
Objectives: To estimate the prevalence of leisure-time physical inactivity (LTPI) and associated factors among healthcare workers. Material and Methods: The cross-sectional study carried out with 2684 healthcare workers from 4 municipalities from the northeast region, Brazil. The LTPI was assessed by dichotomous question. The association between LTPI and the various independent variables was examined through the multinomial logistic regression analysis (crude and adjusted). Results: The prevalence of LTPI was 47.9\% (95\% confidence interval (CI): 46.01-48.80). The adjusted analysis (sociodemographic and occupational characteristics) showed that women and individuals with higher levels of education were more LTPI $(p=0.05)$. Conclusions: The prevalence of LTPI was high among the population investigated, especially among women and individuals with higher education. These results show the importance of developing actions to encourage adherence to physical activity during leisure time among workers, especially among the most vulnerable groups (people with higher education and women), given the benefits of this behavior to health. Int J Occup Med Environ Health 2018;31(3):251-260
\end{abstract}

Key words:

Inactive leisure time, Leisure-time physical activity, Sedentary lifestyle, Healthcare workers,

Determinants of physical activity, Leisure activities

\section{INTRODUCTION}

Physical inactivity (PI) is one of the major public health problems of the twenty-first century, being the fourth risk factor for mortality among all other causes in the world [1]. According to the World Health Organization [2], 31\% of adults in the world are physically inactive and about 3.2 million deaths/year are due to PI. The region of the Americas and the Mediterranean [2] and the countries with better Human Development Index (HDI) [3] have the highest percentage of physically inactive individuals. On the other hand, regular physical activity (PA) reduces the risk of cardiovascular disease, cancer and mortality from other causes [4]. Besides, PA may increase life expectancy between 1.5 to 4.5 years depending on the intensity of the physical activities practiced [5].

Data from studies involving healthcare workers showed that the prevalence of PI ranged from 34.8\% [6] and $87.8 \%$ [7], depending on where the professionals worked. Physical inactivity among health professionals is worrying,

Received: August 24, 2016. Accepted: January 26, 2017.

Corresponding author: S. Vasconcelos Rocha, State University of the Southwest of Bahia, Health Department II, Street José Moreira Sobrinho, N/N,45200000, Jequié, Brazil (e-mail: svrocha@uesb.edu.br). 
as these workers are in a strategic position to raise awareness of the population to adopt an active lifestyle [7].

Some factors, such as unfavorable working conditions may influence the lifestyle of the workers [8,9], as stress at work (mainly related to a passive job) is related to the reduction of physical activity in leisure time [8,9]. In contrast, exposure to work activities with learning opportunities and high capacity of decision on the tasks carried out increases the likelihood of increased physical activity in leisure time [10]. Additionally, sociodemographic characteristics such as female gender [6,7], increasing age [11] and lower levels of education are related to the increase in physical inactivity [12].

Considering that knowledge and monitoring of the PI is an important tool to establish incentive strategies and monitoring of physical activity promotion policies, this study aims at estimating the prevalence of leisure-time physical inactivity (LTPI) and the association of this indicator with sociodemographic and occupational characteristics, in the healthcare workers in municipalities from northeastern Brazil.

\section{MATERIAL AND METHODS}

It is a cross-sectional study based on the survey "Working conditions, employment and health conditions of healthcare workers in Bahia" conducted in 2011 and 2012 in 4 municipalities (Feira de Santana, Itabuna, Jequié and Santo Antonio de Jesus). The State of Bahia is located in the northeast of Brazil and occupies the 22nd position in the Human Development Index (HDI) among the states of the country (HDI $=0.66)$.

\section{Study population}

The population of interest included healthcare workers, grouped in primary care and medium complexity from the municipal health systems of the included municipalities. The selection of the study areas was performed by stratified sampling in geographical units, level of complexity and occu- pation, considering the percentage of participation through the stratification variables. The selection of geographical units (municipalities) included was carried out considering the geographical division established by Attention Centers for Family Health (ACFH) of the municipalities.

Workers were selected by adopting random procedures in each stratum, from the information on the number of workers provided by municipal health secretaries and updated by the research team. The sample was obtained assuming the estimated prevalence of the event of interest with the highest prevalence in the case of work accidents (42.9\%) sampling error of 3\% and 95\% confidence. The selected workers were contacted at their workplaces by trained interviewers. Three attempts were made to locate the raffled employee. If the worker wasn't located he was replaced in the sample, respecting the geographical area, the level of complexity, occupation and gender. The replacement was made by drawing lots.

The final sample consisted of 2684 workers from the total number of 6191 eligible for the study, being 38.8\% $(\mathrm{N}=1041)$ from the city of Feira de Santana, 23.4\% $(\mathrm{N}=627)$ from Itabuna, $19 \%(\mathrm{~N}=510)$ from Jequié and $18.9 \%(\mathrm{~N}=506)$ from Santo Antonio de Jesus.

Prior to collecting data the drawn professionals were contacted to be told about the objectives of the study, to be asked to participate in the research, delivery of the research form and getting the signature for the Term of Consent. The research protocol was approved by the Ethics Committee in Research (ECR) with human beings of the State University of Feira de Santana (ECR: 0086.0.0059.000-09).

\section{Study variables}

Leisure-time physical inactivity (dependent variable) was assessed by the question: "How often do you perform physical activities (considering the activities in leisure time)? (Never/ 1 to 2 times per week/3 or more times per week)." Those who reported not to participate in regular physical activity in their leisure time were considered inactive in leisure time. 
The explanatory variables included sociodemographic and occupational characteristics. Sociodemographic aspects: gender; age (categorized from tertiles: < 35, 35-46, $>46$ years old); education (primary, secondary, higher); and geographical unit (Feira de Santana, Itabuna, Santo Antônio de Jesus and Jequié). Occupational characteristics: type of occupation (doctor, nurse/nursing technicians, other health professionals, health agents and administrative); weekly working hours ( $\leq 40 \mathrm{~h},>40 \mathrm{~h}$ ) and psychosocial work factors (assessed through the Job Content Questionnaire - JCQ), validated for Brazilian workers [13]. The JCQ evaluates aspects related to social and psychological structure. For the construction of the indicators coming from the JCQ, the related variables were added, as indicated by the JCQ Center manual [14]. Then the dichotomization of the demand (high and low) and control (high and low) was made using the median of the variables as the cutoff point.

\section{Statistics}

For the purpose of the descriptive analyzes, averages, standard deviations and proportion were used. The $\mathrm{Chi}^{2}$ test was used for comparing the prevalence of LTPI with the explanatory variables. The association between LTPI and the explanatory variables (sociodemographic and occupational) were assessed using regression and adjusted mul- tinomial logistic (odds ratio (OR) and 95\% confidence interval (CI)). The category "never do any physical activity in leisure time" was used as reference. In the adjusted analysis, the variables that presented $p \leq 0.20$ in the crude analysis were included. In all analyzes the 5\% significance level was adopted, using the SPSS software, version 22.0.

\section{RESULTS}

The final sample comprised 2684 workers being women in $78.4 \%$. Their age ranged from 19 to $82(38.38 \pm 10.1)$ years old. The remaining characteristics of the sample are described in the Table 1. Most workers attended high school, worked in the city of Feira de Santana, served as health agents, had working hours up to $40 \mathrm{~h}$. With regard to psychosocial factors at work, $51.7 \%$ fell within the group with high psychological demands, $56.3 \%$ had high control over work and $59.9 \%$ reported high physical demand in industrial activities. Out of the total sample, $99.1 \%$ answered the question of physical inactivity (PI) and the frequency of LTPI was $47.9 \%$. The data in the Table 2 shows the frequency of LTPI according to the independent variables. The LTPI was significantly higher among the women, in the case of individuals who had completed elementary education, worked in the municipality of Feira de Santana and among nurses/nursing technicians $(\mathrm{p}=0.05)$.

Table 1. Characteristics of the study group - healthcare workers from 4 municipalities*, State of Bahia, Brazil, 2011-2012

\begin{tabular}{lccc}
\hline & \multicolumn{3}{c}{$\begin{array}{c}\text { Respondents } \\
(\mathrm{N}=2684)\end{array}$} \\
\cline { 2 - 4 } & Variable & $\mathrm{n}$ & $\%$ \\
\cline { 2 - 4 } & $\begin{array}{c}\text { survey answer rate } \\
{[\%]}\end{array}$ & 99.7 & \\
\hline $\begin{array}{l}\text { Gender } \\
\text { female }\end{array}$ & & 2099 & 78.4 \\
$\quad$ male & & 578 & 21.6 \\
Age & 97.6 & & \\
$<35$ years & & 1103 & 42.1 \\
$35-46$ years & & 937 & 35.8 \\
$>46$ years & & 580 & 22.1 \\
\hline
\end{tabular}


Table 1. Characteristics of the study group - healthcare workers from 4 municipalities*, State of Bahia, Brazil, 2011-2012 - cont.

\begin{tabular}{|c|c|c|c|}
\hline \multirow{2}{*}{ Variable } & \multicolumn{3}{|c|}{$\begin{array}{l}\text { Respondents } \\
(\mathrm{N}=2684)\end{array}$} \\
\hline & $\begin{array}{c}\text { survey answer rate } \\
{[\%]}\end{array}$ & $\mathrm{n}$ & $\%$ \\
\hline Education & 98.5 & & \\
\hline higher & & 1115 & 42.2 \\
\hline secondary & & 1415 & 53.6 \\
\hline elementary & & 111 & 4.2 \\
\hline Geographical unit & 100.0 & & \\
\hline Itabuna & & 627 & 23.4 \\
\hline Feira de Santana & & 1041 & 38.8 \\
\hline Santo Antônio de Jesus & & 506 & 18.9 \\
\hline Jequié & & 510 & 19.0 \\
\hline Occupation & 99.7 & & \\
\hline administrative & & 732 & 27.4 \\
\hline other healthcare professionals & & 183 & 6.8 \\
\hline nurse/nursing technicians & & 522 & 19.5 \\
\hline health agents & & 1108 & 41.4 \\
\hline doctor & & 130 & 4.9 \\
\hline Working time & 96.8 & & \\
\hline$>40 \mathrm{~h} / \mathrm{week}$ & & 546 & 21.0 \\
\hline$\leq 40 \mathrm{~h} /$ week & & 2052 & 79.0 \\
\hline \multicolumn{4}{|l|}{ Demands } \\
\hline physical & 93.2 & & \\
\hline high & & 1499 & 59.9 \\
\hline low & & 1033 & 40.1 \\
\hline psychological & 94.0 & & \\
\hline high & & 1303 & 51.7 \\
\hline low & & 1219 & 48.3 \\
\hline Job control & 97.2 & & \\
\hline high & & 1468 & 56.3 \\
\hline low & & 1140 & 43.7 \\
\hline \multicolumn{4}{|l|}{ Strain } \\
\hline high & 91.7 & & \\
\hline yes & & 1992 & 80.9 \\
\hline no & & 470 & 19.1 \\
\hline
\end{tabular}


Table 1. Characteristics of the study group - healthcare workers from 4 municipalities*, State of Bahia, Brazil, 2011-2012 - cont.

\begin{tabular}{|c|c|c|c|}
\hline \multirow{2}{*}{ Variable } & \multicolumn{3}{|c|}{$\begin{array}{l}\text { Respondents } \\
(\mathrm{N}=2684)\end{array}$} \\
\hline & $\begin{array}{c}\text { survey answer rate } \\
{[\%]}\end{array}$ & $\mathrm{n}$ & $\%$ \\
\hline \multicolumn{4}{|l|}{ Strain } \\
\hline low & 91.7 & & \\
\hline yes & & 1375 & 55.8 \\
\hline no & & 1087 & 44.2 \\
\hline \multicolumn{4}{|l|}{ Work } \\
\hline active & 91.7 & & \\
\hline yes & & 470 & 19.1 \\
\hline no & & 1992 & 80.9 \\
\hline passive & 91.7 & & \\
\hline yes & & 1087 & 44.2 \\
\hline no & & 1375 & 55.8 \\
\hline Leisure-time physical activity & 99.1 & & \\
\hline never & & 1274 & 47.9 \\
\hline 1-2 times/week & & 706 & 26.6 \\
\hline$\geq 3$ times/week & & 679 & 25.5 \\
\hline
\end{tabular}

* From the city of: Feira de Santana - 38.8\% ( $=1041)$, Itabuna - 23.4\% ( $=627$ ), Jequié $-19 \%$ ( $\mathrm{N}=510)$, and Santo Antonio de Jesus $-18.9 \%$ $(\mathrm{N}=506)$.

Table 2. Physical activity (PA) in leisure time according to socio-demographic and occupational characteristics of healthcare workers, State of Bahia, Brazil, 2011-2012

\begin{tabular}{|c|c|c|c|c|c|c|c|}
\hline & \multicolumn{6}{|c|}{$\mathrm{PA}$} & \multirow{3}{*}{$\mathrm{p}$} \\
\hline Variable & \multicolumn{2}{|c|}{ never } & \multicolumn{2}{|c|}{ 1-2 times/week } & \multicolumn{2}{|c|}{$\geq 3$ times/week } & \\
\hline & $\mathrm{n}$ & $\%$ & $\mathrm{n}$ & $\%$ & $\mathrm{n}$ & $\%$ & \\
\hline Gender & & & & & & & $<0.001$ \\
\hline male & 162 & 38.3 & 220 & 38.5 & 190 & 33.2 & \\
\hline female & 1109 & 53.3 & 484 & 23.2 & 489 & 23.5 & \\
\hline Age & & & & & & & 0.20 \\
\hline$<35$ years & 504 & 46.1 & 296 & 27.1 & 294 & 26.9 & \\
\hline $35-46$ years & 474 & 51.0 & 238 & 25.6 & 218 & 23.4 & \\
\hline$>46$ years & 269 & 46.8 & 157 & 27.3 & 149 & 25.9 & \\
\hline Education & & & & & & & $<0.001$ \\
\hline elementary & 75 & 68.8 & 20 & 18.3 & 14 & 12.8 & \\
\hline secondary & 719 & 51.2 & 353 & 25.2 & 331 & 23.6 & \\
\hline higher & 461 & 41.6 & 323 & 29.2 & 324 & 29.2 & \\
\hline
\end{tabular}


Table 2. Physical activity (PA) in leisure time according to socio-demographic and occupational characteristics of healthcare workers, State of Bahia, Brazil, 2011-2012 - cont.

\begin{tabular}{|c|c|c|c|c|c|c|c|}
\hline \multirow{3}{*}{ Variable } & \multicolumn{6}{|c|}{ PA } & \multirow{3}{*}{$\mathrm{p}$} \\
\hline & \multicolumn{2}{|c|}{ never } & \multicolumn{2}{|c|}{ 1-2 times/week } & \multicolumn{2}{|c|}{$\geq 3$ times/week } & \\
\hline & $\mathrm{n}$ & $\%$ & $\mathrm{n}$ & $\%$ & $\mathrm{n}$ & $\%$ & \\
\hline Geographical unit & & & & & & & $<0.001$ \\
\hline Itabuna & 286 & 46.1 & 170 & 27.4 & 164 & 26.5 & \\
\hline Feira de Santana & 519 & 50.2 & 228 & 22.1 & 287 & 27.8 & \\
\hline Santo Antônio de Jesus & 247 & 49.0 & 140 & 27.8 & 117 & 23.2 & \\
\hline Jequié & 222 & 44.3 & 168 & 33.5 & 111 & 22.2 & \\
\hline Occupation & & & & & & & $<0.001$ \\
\hline administrative & 356 & 49.0 & 188 & 25.9 & 183 & 25.2 & \\
\hline other healthcare & 55 & 30.1 & 48 & 26.2 & 80 & 43.7 & \\
\hline nurses & 273 & 52.7 & 133 & 25.7 & 112 & 21.6 & \\
\hline health agents & 548 & 50.1 & 290 & 26.5 & 256 & 23.4 & \\
\hline doctors & 39 & 30.0 & 44 & 33.8 & 47 & 36.2 & \\
\hline Working time & & & & & & & 0.08 \\
\hline$\leq 40 \mathrm{~h} /$ week & 998 & 49.0 & 526 & 25.8 & 513 & 25.2 & \\
\hline$>40 \mathrm{~h} /$ week & 237 & 43.6 & 153 & 28.2 & 153 & 28.2 & \\
\hline \multicolumn{8}{|l|}{ Demands } \\
\hline physical & & & & & & & 0.20 \\
\hline high & 727 & 49.0 & 393 & 26.5 & 363 & 24.5 & \\
\hline low & 469 & 47.1 & 261 & 26.2 & 266 & 26.7 & \\
\hline psychological & & & & & & & 0.19 \\
\hline high & 615 & 47.7 & 333 & 25.8 & 341 & 26.5 & \\
\hline low & 584 & 48.2 & 334 & 27.6 & 293 & 24.2 & \\
\hline Job control & & & & & & & 0.06 \\
\hline high & 708 & 48.5 & 365 & 25.0 & 386 & 26.5 & \\
\hline low & 532 & 47.2 & 326 & 28.9 & 269 & 23.9 & \\
\hline
\end{tabular}

The results of the multinomial logistic regression analysis showed that women were more likely to be physically inactive during leisure time ( $\mathrm{OR}=2.45,95 \% \mathrm{CI}: 1.86-3.23)$ when compared to men. The prevalence of an individual with elementary school in terms of LTPI in relation to the ones who practice 3 or more days per week of physical activity in leisure time is $77 \%$ lower than those with higher education, controlling all other variables (Table 3 ).

\section{DISCUSSION}

In this study, approximately a half of the studied population was physically inactive in leisure time (47.9\%) and this behavior was more pronounced among women and individuals with higher levels of education.

The prevalence of LTPI among healthcare workers differs amongst studies $[7,12,15]$. In a survey involving healthcare professionals working in primary health care in mu- 
Table 3. Association between leisure-time physical activity (LTPA) with sociodemographic and occupational variables among healthcare workers, State of Bahia, Brazil, 2011-2012

\begin{tabular}{|c|c|c|c|c|}
\hline \multirow[t]{2}{*}{ Variable } & \multicolumn{2}{|c|}{$\begin{array}{l}\text { Crude analysis } \\
(\mathrm{OR}(95 \% \mathrm{CI}))\end{array}$} & \multicolumn{2}{|c|}{$\begin{array}{c}\text { Adjusted analysis } \\
(\mathrm{OR}(95 \% \mathrm{CI}))\end{array}$} \\
\hline & never vs. 1-2 times/week & never vs. $\geq 3$ times/week & never vs. $1-2$ times/week & never vs. $\geq 3$ times/week \\
\hline \multicolumn{5}{|l|}{ Gender } \\
\hline male & 1 & 1 & 1 & 1 \\
\hline female & $3.24(2.53-4.16)$ & $2.44(1.89-3.16)$ & $3.18(2.44-4.15)$ & $2.45(1.86-3.23)$ \\
\hline \multicolumn{5}{|l|}{ Age } \\
\hline$<35$ years & $1.04(0.80-1.35)$ & $1.15(0.85-1.45)$ & $0.24(0.12-0.47)$ & $0.78(0.58-1.04)$ \\
\hline $35-46$ years & $0.83(0.64-1.10)$ & $0.85(0.64-1.12)$ & $0.76(0.58-0.95)$ & $0.87(0.65-1.17)$ \\
\hline$>46$ years & 1 & 1 & 1 & 1 \\
\hline \multicolumn{5}{|l|}{ Education } \\
\hline elementary & $0.68(0.56-0.84)$ & $0.25(0.13-0.48)$ & $0.24(0.12-0.47)$ & $0.23(0.11-0.45)$ \\
\hline secondary & $0.30(0.16-0.54)$ & $0.64(0.52-0.79)$ & $1.35(1.17-1.57)$ & $0.75(0.59-0.96)$ \\
\hline higher & 1 & 1 & 1 & 1 \\
\hline \multicolumn{5}{|l|}{ Geographical unit } \\
\hline Itabuna & 1 & 1 & 1 & 1 \\
\hline Feira de Santana & $0.68(0.52-0.89)$ & $0.96(0.73-1.25)$ & $0.87(0.65-1.15)$ & $1.21(0.91-1.60)$ \\
\hline $\begin{array}{l}\text { Santo Antônio } \\
\text { de Jesus }\end{array}$ & $0.94(0.69-1.28)$ & $0.83(0.60-1.15)$ & $1.10(0.79-1.51)$ & $0.93(0.66-1.30)$ \\
\hline Jequié & $1.15(0.83-1.57)$ & $0.90(0.64-1.27)$ & $1.49(1.06-2.08)$ & $1.19(0.83-1.70)$ \\
\hline \multicolumn{5}{|l|}{ Occupation } \\
\hline administrative & 1 & 1 & 1 & 1 \\
\hline $\begin{array}{l}\text { other healthcare } \\
\text { professionals }\end{array}$ & $1.68(1.04-2.70)$ & $3.01(1.95-4.64)$ & $1.37(0.82-2.28)$ & $2.46(1.53-3.93)$ \\
\hline $\begin{array}{l}\text { nurses/nursing } \\
\text { technicians }\end{array}$ & $0.86(0.64-1.17)$ & $0.88(0.65-1.19)$ & $0.99(0.72-1.38)$ & $0.87(0.67-1.20)$ \\
\hline health agents & $0.95(0.75-1.22)$ & $0.92(0.72-1.19)$ & $1.03(0.79-1.35)$ & $0.91(0.69-1.19)$ \\
\hline doctors & $2.27(1.31-3.90)$ & $2.06(1.17-3.63)$ & $1.30(0.70-2.10)$ & $1.21(0.65-2.27)$ \\
\hline \multicolumn{5}{|l|}{ Working time } \\
\hline$\leq 40 \mathrm{~h} /$ week & $0.78(0.60-0.99)$ & $0.79(0.62-1.02)$ & $1.01(0.75-1.33)$ & $1.07(0.81-1.42)$ \\
\hline$>40 \mathrm{~h} /$ week & 1 & 1 & 1 & 1 \\
\hline \multicolumn{5}{|l|}{ Demands } \\
\hline \multicolumn{5}{|l|}{ physical } \\
\hline high & 1 & 1 & 1 & 1 \\
\hline low & $1.04(0.85-1.28)$ & $1.13(0.95-1.15)$ & $0.99(0.79-1.23)$ & $1.10(0.88-1.36)$ \\
\hline \multicolumn{5}{|l|}{ psychological } \\
\hline high & 1 & 1 & 1 & 1 \\
\hline low & $1.12(0.91-1.37)$ & $0.91(0.75-1.12)$ & $1.24(0.94-1.64)$ & $0.84(0.64-1.11)$ \\
\hline
\end{tabular}


Table 3. Association between leisure-time physical activity (LTPA) with sociodemographic and occupational variables among healthcare workers, State of Bahia, Brazil, 2011-2012 - cont.

\begin{tabular}{|c|c|c|c|c|}
\hline \multirow[t]{2}{*}{ Variable } & \multicolumn{2}{|c|}{$\begin{array}{l}\text { Crude analysis } \\
(\mathrm{OR}(95 \% \mathrm{CI}))\end{array}$} & \multicolumn{2}{|c|}{$\begin{array}{l}\text { Adjusted analysis } \\
(\mathrm{OR}(95 \% \mathrm{CI}))\end{array}$} \\
\hline & never vs. $1-2$ times/week & never vs. $\geq 3$ times/week & never vs. 1-2 times/week & never vs. $\geq 3$ times/week \\
\hline \multicolumn{5}{|l|}{ Job control } \\
\hline high & 1 & 1 & 1 & 1 \\
\hline low & $1.22(1.01-1.50)$ & $0.92(0.75-1.13)$ & $0.97(0.72-1.31)$ & $0.94(0.69-1.28)$ \\
\hline
\end{tabular}

OR - odds ratio; $\mathrm{CI}$ - confidence interval.

Bolded values - statistically significant at $\mathrm{p} \leq 0.05$.

nicipalities in the southern and northeastern Brazil [15], the prevalence of physical inactivity (PI) was $27.5 \%$. The time trend study conducted among workers of Centers for Psychosocial Care (CPC) of municipalities of southern Brazil showed that the prevalence of PI was high $(76.8 \%$ in 2006 and $82.4 \%$ in 2011) [12]. In the study of SanabriaRojas et al. [7] conducted among primary care workers in Peru, the prevalence of PI was $87.8 \%$. Possibly, the difference in the observed prevalence of PI among these studies, due to the methods and dimensions of physical activity evaluated, sample selection, included professional categories, workplace and the age of the participants.

The adjusted analysis identified that the women were positively associated with LTPI, independently from adjustments for sociodemographic and occupational factors. These results are worrying because exposure to LTPI increases the risk of mortality among women [4]. A previous study involving healthcare workers showed that women were more inactive in leisure time [11]. The reduction in physical activity during leisure time may be linked to the fact that many Brazilian women are still responsible for carrying out the domestic work [16] and this should be the reality of healthcare workers. In this sense, the accumulation of domestic activities with work may decrease the time for leisure activities.

The results have shown an inverse association between schooling and LTPI. The access to the best educational levels is related to the reduction of risk factors for chronic diseases such as smoking, poor diet and physical inactivity [17]. Besides, increased education and income facilitate access to spaces for physical activity, which are mostly private [16]. However, studies with healthcare workers $[12,18]$ are not conclusive with respect to the direction of this association. A survey carried out with workers in psychosocial care centers in southern Brazil found that workers with higher levels of education were less physically inactive [12]. On the other hand, in a study with primary care workers in the southern and northeastern Brazil, the authors [18] found that higher levels of education were associated with PI.

Despite not having observed the association between occupational characteristics and LTPI, these may relate to increased LTPI. In developing countries, issues such as low pay, lack of a plan for jobs and wages, high working hours do matter, indeed [19]. In developed countries, work stressors such as poor decision making, low support from co-workers, employer intolerance, discrimination in the workplace, work-family imbalance in the relationship and night work [19] contribute to reducing the time available for physical activity, recreation and health care.

Some limitations of this study should be considered. A cross-sectional study does not provide direct causal relationships. The assessment of the level of physical activity 
through a dichotomous question, despite being a simple and easily applied method, widely used in epidemiological studies [20-22] may underestimate or overestimate some information. Extrapolation of the data must be done with caution because this study has included workers from a region of Brazil, a country with regional disparities related to cultural aspects and lifestyle.

As strengths of the study, it is emphasized that in this study a population-based survey was carried out in $4 \mathrm{mu}-$ nicipalities of the largest state in northeastern of Brazil. Other strengths are the sample selection, the training of researchers and the standardization of data collection, in addition to the use of an instrument validated for assessment of occupational stress (JCQ), widely used among the working population.

\section{CONCLUSIONS}

Despite the importance of physical activity for the health of the population, there was a high percentage of LTPI individuals among the study population. Sociodemographic characteristics (female and higher education levels) are associated with increased LTPI. The results indicate the need for further actions to encourage the practice of physical activity in leisure time and the adoption of an active lifestyle among healthcare workers, especially among the most vulnerable groups in order to reduce the LTPI among this population.

\section{REFERENCES}

1. World Health Organization. Global recommendations on physical activity for health. Geneva: The Organization; 2010.

2. World Health Organization. A global public health concern physical inactivity: A global public health problem. Geneva: The Organization; 2015.

3. Dumith SC, Hallal PC, Reis RS, Kohl HW. Worldwide prevalence of physical inactivity and its association with human development index in 76 countries. Prev Med. 2011;53(1-2): 24-8, https://doi.org/10.1016/j.ypmed.2011.02.017.
4. Huerta JM, Chirlaque MD, Tormo MJ, Buckland G, Ardanaz E, Arriola L, et al. Work, household, and leisure-time physical activity and risk of mortality in the EPIC-Spain cohort. Prev Med. 2016;85:106-12, https://doi.org/10.1016/ j.ypmed.2016.02.009.

5. Holtermann A, Marott JL, Gyntelberg F, Søgaard K, Suadicani P, Mortensen O, et al. Does the benefit on survival from leisure time physical activity depend on physical activity at work? A prospective cohort study. PLoS One. 2013;8(1):e54548, https://doi.org/10.1371/journal.pone. 0054548 .

6. Banday AH, Want FA, Alris FFA, Alrayes MF, Alenzi MJ. A cross-sectional study on the prevalence of physical activity among primary health care physicians in Aljouf region of Saudi Arabia. Mater Sociomed. 2015;27(4):263-6, https:// doi.org/10.5455/msm.2015.27.263-266.

7. Sanabria-Rojas H, Tarqui-Mamani C, Portugal-Benavides W, Pereyra-Zaldívar H, Mamani-Castillo L. [The physical activity level of people working at a regional health office in Lima, Peru]. Rev Salud Publica. 2014;16(1):53-62, https://doi.org/10.15446/rsap.v16n1.38672. Spanish.

8. Fransson EI, Heikkilä K, Nyberg ST, Zins M, Westerlund H, Westerholm P, et al. Job strain as a risk factor for leisure-time physical inactivity: An individual-participant meta-analysis of up to 170000 men and women: The IPD-Work Consortium. Am J Epidemiol. 2012;176(12):1078-89, https://doi. org/10.1093/aje/kws336.

9. Fanavoll R, Nilsen TIL, Holtermann A, Mork PJ. Psychosocial work stress, leisure time physical exercise and the risk of chronic pain in the neck/shoulders: Longitudinal data from the Norwegian HUNT Study. Int J Occup Med Environ Health. 2016;29(4):585-95, https://doi.org/10.13075/ ijomeh.1896.00606.

10. Choi B, Schnall P, Yang H, Dobson M, Landsbergis P, Israel L, et al. Psychosocial working conditions and active leisure-time physical activity in middle-aged US workers. Int J Occup Med Environ Health. 2010;23(3):239-53, https:// doi.org/10.2478/v10001-010-0029-0. 
11. Li X, Cheng M, Zhang H, Ke T, Chen Y. Prevalence and determinations of physical inactivity among public hospital employees in Shanghai, China: A cross-sectional study. Front Med. 2015;9(1):100-7, https://doi.org/10.1007/s11684014-0372-9.

12. Jerônimo JS, Jardim VMDR, Kantorski LP, Domingues MR. [Physical activity in staff workers at Centers for Psychosocial Care in southern Brazil: Temporal Trends]. Cad Saude Publica. 2014;30(12):2656-68, https://doi.org/ 10.1590/0102-311X00049414. Portuguese.

13. Araújo TM, Karasek R. Validity and reliability of the job content questionnaire in formal and informal jobs in Brazil. Scand J Work Environ Health. 2008;(6):52-9.

14. Karasek R. Job content questionnaire and user's guide: Department of Work environment [Internet]. Lowell: University of Massachusetts; 1995 [cited 2016 Jul 16]. Avaliable from: https://www.jcqcenter.org.

15. Dilélio AS, Facchini LA, Tomasi E, Silva SM, Thumé E, Piccini RX, et al. [Prevalence of minor psychiatric disorders among primary healthcare workers in the South and Northeast regions of Brazil]. Cad Saude Publica. 2012;28(3):50314, https://doi.org/10.1590/S0102-311X2012000300011. Portuguese.

16. Moura EC, da Silva SA, Malta DC, Morais-Neto OL. [Risk and protective factors for chronic non-communicable diseases: The VIGITEL telephone disease surveillance system, Brazil, 2007]. Cad Saude Publica. 2011;27(3):486-96, https:// doi.org/10.1590/S0102-311X2011000300009. Portuguese.

17. Silva DAS, Peres KG, Boing AF, González-Chica DA, Peres MA. Clustering of risk behaviors for chronic noncom- municable diseases: A population-based study in southern Brazil Prev Med. 2013;56(1):20-4, https://doi.org/10.1016/ j.ypmed.2012.10.022.

18. Siqueira FCV, Nahas MV, Facchini LA, Piccini RX, Tomasi E, Thumé E, et al. [Physical activity among health professionals from South and Northeast Brazil]. Cad Saude Publica. 2009;25(9):1917-28, https://doi.org/10.1590/S0102311X2009000900006. Portuguese.

19. Lima DMG, Araújo RC, Pitangui ACR, Rizzo JA, Sarinho SW, Santos SMA, et al. [Description of physical activity and working hours in the quality of life of intensive care professionals: Comparison between a large urban center and an interior city of Brazil]. Rev Bras Ativ Fis Saude. 2015;20(4):386-96, https://doi.org/10.12820/rbafs.v.20n4p386. Portuguese.

20. Knuth AG, Malta DC, Dumith SC, Pereira CA, MoraisNeto OL, Temporão JG, et al. [Practice of physical activity and sedentarism among Brazilians: Results of the National Household Sample Survey - 2008]. Cien Saude Colet. 2011;16(9):3697-705, https://doi.org/10.1590/S141381232011001000007. Portuguese.

21. Malta D, Andrade S, Santos M, Rodrigues G, Mielke G. [Trends of physical activity indicators in adults: State $\mathrm{Ca}$ pitals of Brazil 2006-2013]. Rev Bras Ativ Fis Saude. 2015;20(2):141-51, https://doi.org/10.12820/rbafs.v.20n2p141. Portuguese.

22. Mielke GI, Hallal PC, Rodrigues GBA, Szwarcwald CL, Santos FV, Malta DC. [Physical activity and television viewing among Brazilian adults: National Health Survey 2013]. Epidemiol Serv Saude. 2015;24(2):277-86, https://doi. org/10.5123/S1679-49742015000200010. Portuguese.

This work is available in Open Access model and licensed under a Creative Commons Attribution-NonCommercial 3.0 Poland License - http://creativecommons.org/ licenses/by-nc/3.0/pl/deed.en. 